\title{
MONITORING OF THE GROUND DEFORMATION IN PENANG ISLAND, MALAYSIA USING PERMANENT SCATTERER INTERFEROMETRY SYNTHETIC APERTURE RADAR (PS-INSAR) AND GROUND-PENETRATING RADAR (GPR) TECHNIQUES
}

\author{
Kazeem Olukunle RAUFF ${ }^{1,2)} *$ and Ismail Ahmad ABIR ${ }^{1)} *$ \\ ${ }^{1)}$ School of Physics, Universiti Sains Malaysia, Penang Island,11800, Malaysia \\ ${ }^{2)}$ Federal University of Kashere, P.M.B. 0182, Gombe, Nigeria \\ *Corresponding author's e-mail: olukunleid@gmail.com; iahmadabir@usm.my
}

\begin{tabular}{|c|c|}
\hline ARTICLE INFO & ABSTRACT \\
\hline Article history: & \multirow{10}{*}{$\begin{array}{l}\text { Ground deformations (e.g., landslide and subsidence) have substantially risen recently around } \\
\text { Penang Island, Malaysia. The development of hillslopes for rapid urbanisation and heavy rainfall } \\
\text { has detrimental impacts on Penang Island soil layers. Modelling, simulation, and the developmen } \\
\text { of susceptibility maps were past methods used to predict potential ground deformations of Penang } \\
\text { Island. There is no published work on the Interferometry Synthetic Aperture Radar (InSAR) } \\
\text { technique, where ground deformation of the region has been holistically studied. This work } \\
\text { integrates the Persistent Scatterer InSAR (PS-InSAR) technique with Ground Penetrating Radar } \\
\text { (GPR) to monitor the deformation on the island and identify possible subsurface causes for the } \\
\text { disturbance. Twenty-four descending Sentinel-1A datasets acquired between 14th July } 2017 \text { and } \\
\text { 13th October } 2018 \text { were processed to monitor and map ground deformation areas with a focus on } \\
\text { three selected regions- Batu Feringghi (BF), Paya Terubong (PT), and Tanjung Bungah (TB) } \\
\text { where multiple landslides occurred between } 2017 \text { and } 2018 \text {. InSAR results were later analysed } \\
\text { using the Statistical Package for the Social Sciences (SPSS) tool and validated by the available } \\
\text { Global Positioning System (GPS) analysis. InSAR analyses reveal the mean deformation values } \\
\text { of -3.13 mm/yr, -2.76 mm/yr and -4.77 mm/yr for the BF, PT, and TB areas. GPR } \\
\text { surveys were conducted with a } 300 / 800 \mathrm{MHz} \text { dual-frequency antenna at the three selected study } \\
\text { areas. Anomalies (wall cracks, road fissures, cavities, drains, and pipes) detected using GPR } \\
\text { profiles correlated well with the permanent scatterer points calculated using the InSAR technique }\end{array}$} \\
\hline Received 28 April 2021 & \\
\hline Accepted 4 August 2021 & \\
\hline Available online 12 October 2021 & \\
\hline Keywords: & \\
\hline Ground deformations & \\
\hline PS-InSAR & \\
\hline GPR & \\
\hline GPS & \\
\hline Sentinel-1A & \\
\hline
\end{tabular}

\section{INTRODUCTION}

Landslide is the most dominant geohazard that travels many miles without warning, damages infrastructure, and causes loss of lives worldwide (Mirzaee et al., 2017; Rauff et al., 2020a). Human or anthropogenic activities (mining, deforestation, land reclamation, hill cut, etc.), geomorphological processes (erosion, vegetation removal, etc.), and natural activities (rainfall, earthquakes, volcanic eruption, etc.) are among the various mechanisms triggering landslides (Adnan et al., 2005). Penang Island's landslide failure is attributed to persistent rainfall and the cutting of hills for construction due to limited flatlands to cater for urban growth. Some of the past works on ground movement relied on Landsat imagery, aerial photographs, and Geographical Information System (GIS) for modelling, forecasting, and creating susceptibility maps (Lee and Pradhan, 2006; Tan et al., 2009; Pradhan and Lee, 2010; Pradhan et al., 2012). Landslide trends has also be investigated (in aerial photographs) by examining differences in the bare-soil and forest-floor surfaces (Lee and Pradhan, 2006). Multiple traditional systems: an extensometer, a global positioning system (GPS), an inclinometer, etc., have been applied for continuous deformation monitoring to reduce natural hazards. These technologies only cover a limited area and are susceptible to damage during landslide failure (Bayer et al., 2017).

InSAR technique is used in this paper to quantify surface movements of Penang Island for the first time to ensure that the island is worth living on and stable. This paper focuses on the Permanent Scatterer Interferometric Synthetic Aperture Radar (PS-InSAR) technique to process 24 descending Sentinel-1A (S-1A) datasets in SARPROZ software to assess, map, and quantify the ground deformation in three (Batu Feringghi, Paya Terubong, and Tanjung Bungah) areas of Penang Island.

The study also emphasises the significance of quantitative measurements of ground movement to classify landslide-prone areas and provide relevant data for appropriate technical solutions. The details of possible causes of the movement are also provided in the manuscript from the investigation of subsurface characterisation using the Ground Penetrating Radar (GPR) method in the three selected investigated areas. These areas are selected, they are located over various geological formations and have been hit by landslides the most (Ali et al., 2011; Pradhan and Hasan, 2014).

Cite this article as: Rauff KO, Abir IA: Monitoring of the ground deformation in Penang Island, Malaysia using Permanent Scattere Interferometry Synthetic Aperture Radar (PS-InSAR) and Ground-Penetrating Radar (GPR) techniques. Acta Geodyn. Geomater., 18, No. 4 (204), 461-471, 2021. DOI: 10.13168/AGG.2021.0033 


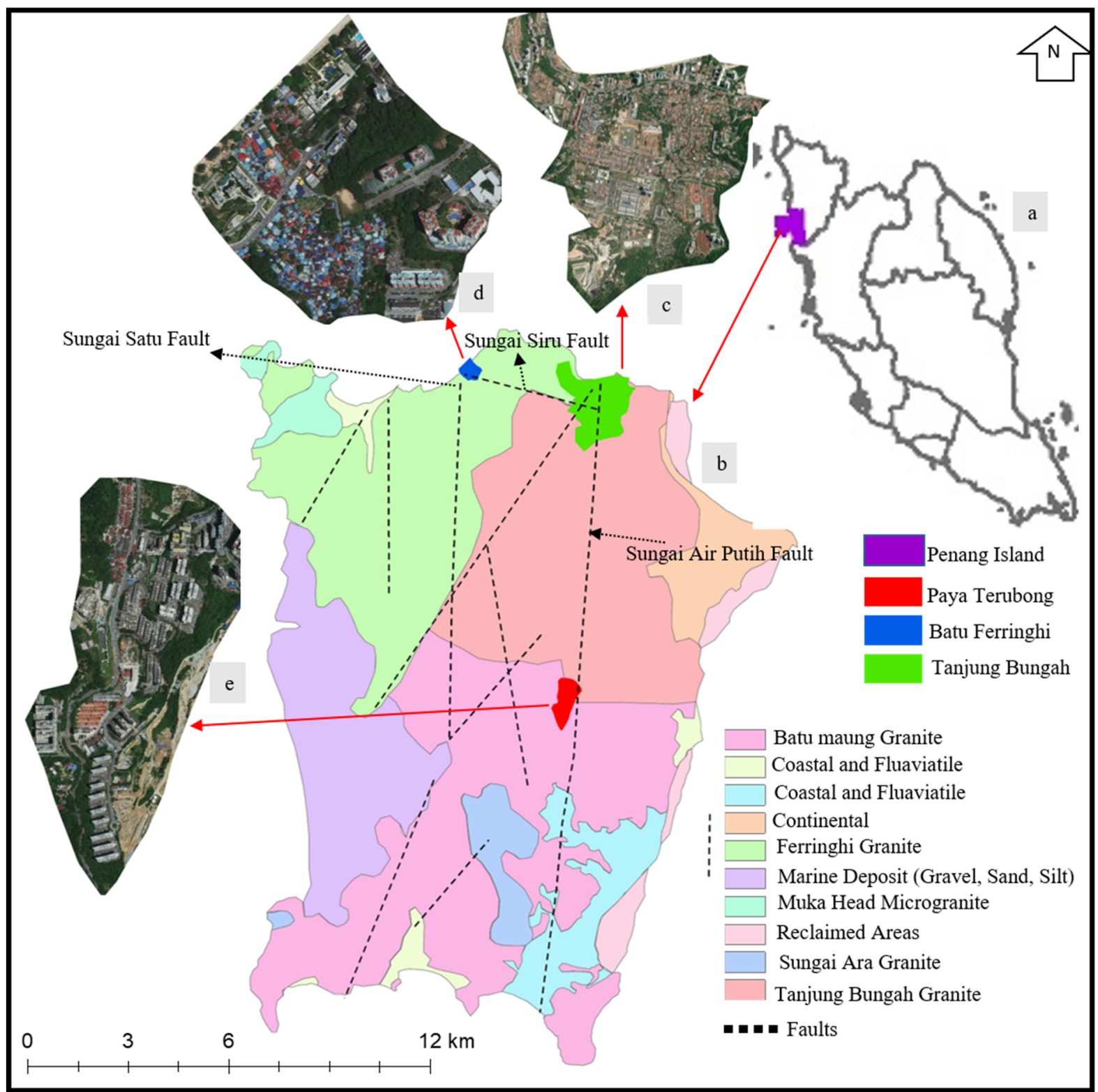

Fig. 1 Map of Malaysia Peninsular (a), map Penang Island (with its geology map Modified after Tan (1994) (b), and the three selected areas (c-e).

\section{STUDY AREA}

As is often the case with island regions globally, Penang Island is densely populated due to the availability of productive resources, access to trade and transport, and tight security that has attracted many people (Chee et al. 2017; Rauff et al., 2020b). The area size is approximately $300 \mathrm{~km}^{2}$ and has a geographical coordinate between longitudes $\left(100^{\circ} 8^{\prime} \mathrm{E}-100^{\circ} 32^{\prime} \mathrm{E}\right)$ and latitudes $\left(5^{\circ} 8^{\prime} \mathrm{N}\right.$ $\left.5^{\circ} 35^{\prime} \mathrm{N}\right)$. It is located off the north-western coast of Peninsular Malaysia (Fig. 1a) and is one of Malaysia's most popular tourist destinations and main economic hubs. The elevation of the study area varies from $0 \mathrm{~m}$ to $420 \mathrm{~m}$ above sea level. Land reclamation, deforestation, and slope cutting are typical practices in the region (Pradhan and Lee, 2010). Together with anomalies in climatic change (such as heavy rainfall), these practices have increased landslide occurrences, claimed many lives, and caused damages to various properties (Khodadad and Jang, 2015). Tanjung Bungah (Fig. 1c), Batu Feringghi (Fig. 1d), and Paya Terubong (Fig. 1e) are the three areas where the studies were performed in this work.

\section{GEOLOGY AND SOIL SERIES OF PENANG ISLAND}

Penang Island consists of coastal plains (situated on both the east and west coasts) and hills (running from the north to the south) with the geological settings shown in Figure 1b. The island's soil comprises residual soil formed by the untransported accumulation of organic material and graded beneath granitic soils (Tan, 1994; Yahaya et al., 2019). The granites have textural and mineralogical differences and compose a unique plutonic complex (Cobbing et al., 1986). The steep soil covers the bulk part of the island, where most landslide occurrences are 


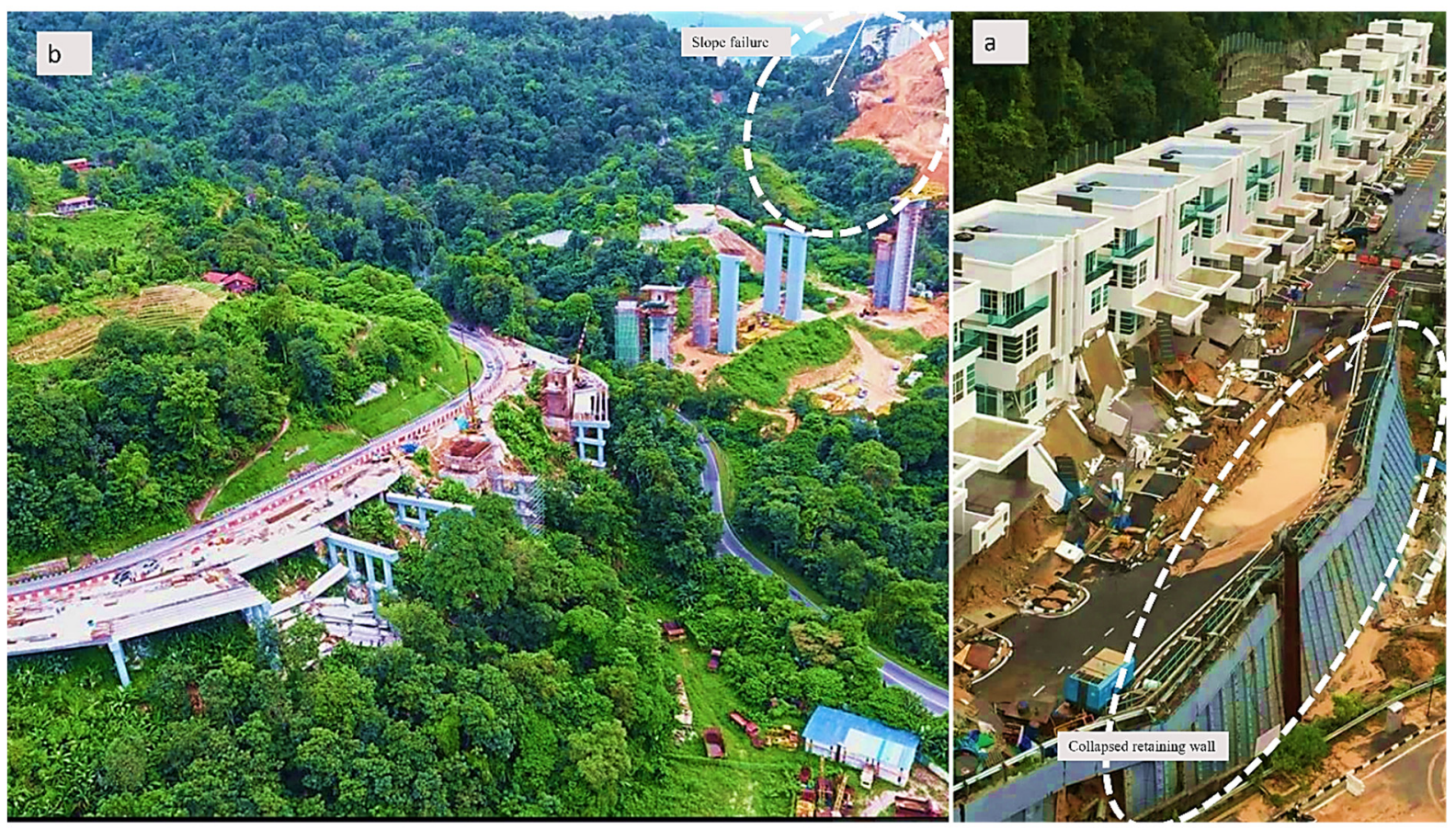

Fig. 2 Landslide distributions in Penang Island between 2017 and 2019. (a) The landslide occurrence at the collapsed retaining wall at Beverly Hills, Tanjung Bungah (modified after Yahaya et al. (2019), and (b) The landslide occurrence at the slope failure at the Bukit Kukus construction site, Paya Terubong (The Star Malaysia, 2019).

registered (Ali et al., 2011). The selected three areas (Batu Ferringhi, Paya Terubong, and Tanjung Bungah) in this research harbour the significant geological formations in Penang Island (Ahmad et al., 2006; Lee and Pradhan, 2006).

\section{BRIEF HISTORY OF PENANG ISLAND LANDSLIDES OCCURRENCES}

There have been various landslide occurrences triggered by heavy rains and floods where different properties and lives have been lost on the island (Fig. 2). One of the incidents was a landslide (near the Sungai Siru fault depicted in Figure $1 b$ that struck a construction site at Beverly Hills, Tanjung Bungah (TB), on $4^{\text {th }}$ November 2017 (Fig. 2a). TB is underlain by granite. It is a tourist hotspot situated on the north coast of the island. Extreme rainfall, which lasted for hours, triggered the slope. The surface runoff exceeded the drainage system's capacity and led to overflowing permeated through the bottom of the filled embankment that supported the road platforms. On $19^{\text {th }}$ October 2018, many lives and assets were lost when a slope at the Bukit Kukus construction site in Paya Terubong (PT) failed due to days of continuous rain (Fig. 2a). PT is a populated area located in the southeast of Penang Island that experiences landslides yearly. Its geology comprises South Penang Pluton (SPP), and it is underlain by massively weathered granite with fluctuating geotechnical properties. The high records of landslide occurrences in PT are due to the main fault (Sungai Air Putih) and weathering processes (Fig. 1b) that cross the area (Ahmad et al.,
2006; Yahaya et al., 2019). The construction site (at PT) involved the clearance of a slope angle of more than $25^{\circ}$. Because of the stream's shallowness, when it rains, the water can become turbulent and overflow into the nearby area, putting the stability of the exposed slopes at risk and triggering landslides.

\section{PERMANENT SCATTERER INTERFEROMETRIC SYNTHETIC APERTURE RADAR (PS-INSAR)}

In this paper, an advanced multi-temporal InSAR, Persistent Scatterer Interferometry (PS-InSAR) technique, has been used to monitor ground deformation in three areas. The technique depends on sending and receiving an active microwave radar signal from a satellite and recording the backscattered pulse by the antenna. It is a versatile radar-based technique that can quantify and monitor surface displacements over time. It is efficient in urban areas where stable and permanent scatterers (PS) are abundant. It is a cost-effective technique to extract information from a complex multiplication of two or more radar phase images acquired in the same area but at different times, which makes up an interferometric pair (Crosetto et al., 2016; Navarro-Sanchez et al., 2014). Among numerous applications of InSAR techniques are subsidence monitoring (Ruiz-Constán et al., 2018) and landslide monitoring in urban areas (Dai et al., 2016). InSAR has also been used for various deformation studies (Farina et al., 2006; Lu, 2007; Paradella et al., 2015; Bakon et al., 2016; Lazecky et al., 2016). 


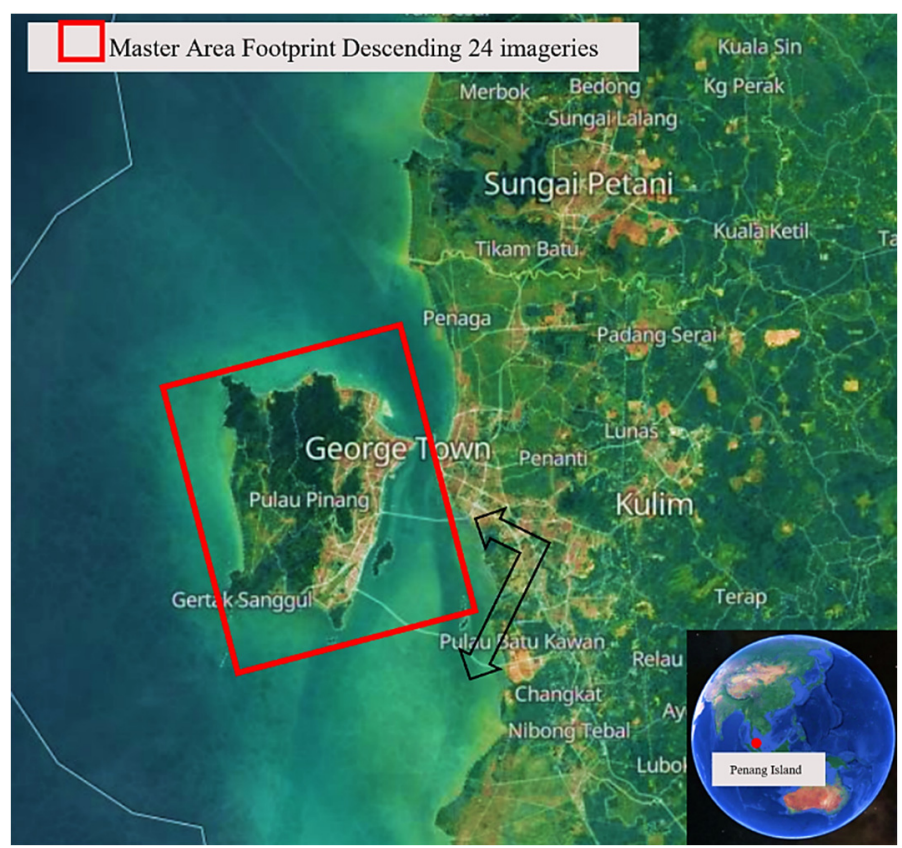

Fig. 3 The footprint of the Map of Penang Island. The white and squares represent the dataset's footprints for the descending orbit.

Table 1 Subset data for Area of Interest (AOI).

\begin{tabular}{lllll}
\hline Orbits & Longitude & Latitude & Radius $(\mathrm{km})$ & Master Images \\
\hline Ascending & 100.1840 & 5.2651 & 21 & April 16, 2018 \\
Descending & 100.2842 & 5.3809 & 20 & March 29, 2018 \\
\hline
\end{tabular}

\section{DATA ACQUISITION}

S-1A satellite works in dual-polarisation modes with a revisit period of 12 days and is currently in operation (in the C-band). The S-1A image was selected because it has good resolution, which allows the investigation of ground deformation, and it is freely available to download after one-time registration (Yague-Martinez et al., 2016). Furthermore, as archived SAR S-1A images are available since 2014, this dataset makes it suitable to monitor Penang Island's ground movement and relate them to recent landslide occurrences. The S-1A IW data are available separately as three (3) products, namely Single Look Complex (SLC), RAW, and Ground Range Dataset (GRD). Twenty-four (24) S-1A images acquired from descending orbit (14 ${ }^{\text {th }}$ July 2017 - 13 ${ }^{\text {th }}$ October 2018) were used to detect, quantify, and map the region's ground displacement. The footprints of the descending S-1A datasets are shown in Figure 3.

\section{METHODOLOGY}

The Permanent Scatterer Interferometric Synthetic Aperture Radar (PS-InSAR) technique was applied to process 24 Sentinel-1A images acquired from 14th July 2017 to 13th October 2018. The generated deformation map was further analysed with the focus on three specific areas (Tanjung Bungah (TB), Batu Ferringhi (BF), and Balik Pulau (BP)) of Penang Island. The acquired datasets were imported into the SARPROZ software developed by Perissin,
Purdue University, West Lafayette, IN, USA (Perissin, 2015). It is a multipurpose software written in Matlab that allows the user to make some modifications (Bakon et al., 2016). The appropriate master image was chosen based on the software's algorithms, considering days without rainfall acquisition. The image acquired on $6^{\text {th }}$ October 2017 was selected as a master image, based on many important parameters like atmospheric condition, doppler centroid, and normal temporal baseline (Sousa et al., 2016; Razi et al., 2018). In short, the applied processing steps are as follows: data subset, master image selection, coregistration of SAR data, processing of reflectivity and amplitude stability index (ASI) maps, ground control point (GCP) selection, selection of external digital elevation model (DEM) and synthetic amplitude in SAR coordinate for persistent scatterers candidates PSC. These steps provided opportunities to generate the reflectivity map and view the DEM in the Area of Interest (AOI). Sparse point selection step was performed to acquire scattered point data in time series analysis. Multi-image sparse grid phase unwrapping, atmospheric phase screen (APS) estimation and removal, PS phase reading, and displacement estimation steps were also performed. The AOI, such as latitude, longitude, and radius, was selected as depicted in Table 1. In the analysis of landslides, an excellent coordinate area is essential, and the size of the extracted area should be limited because of the restriction of the disk space. 

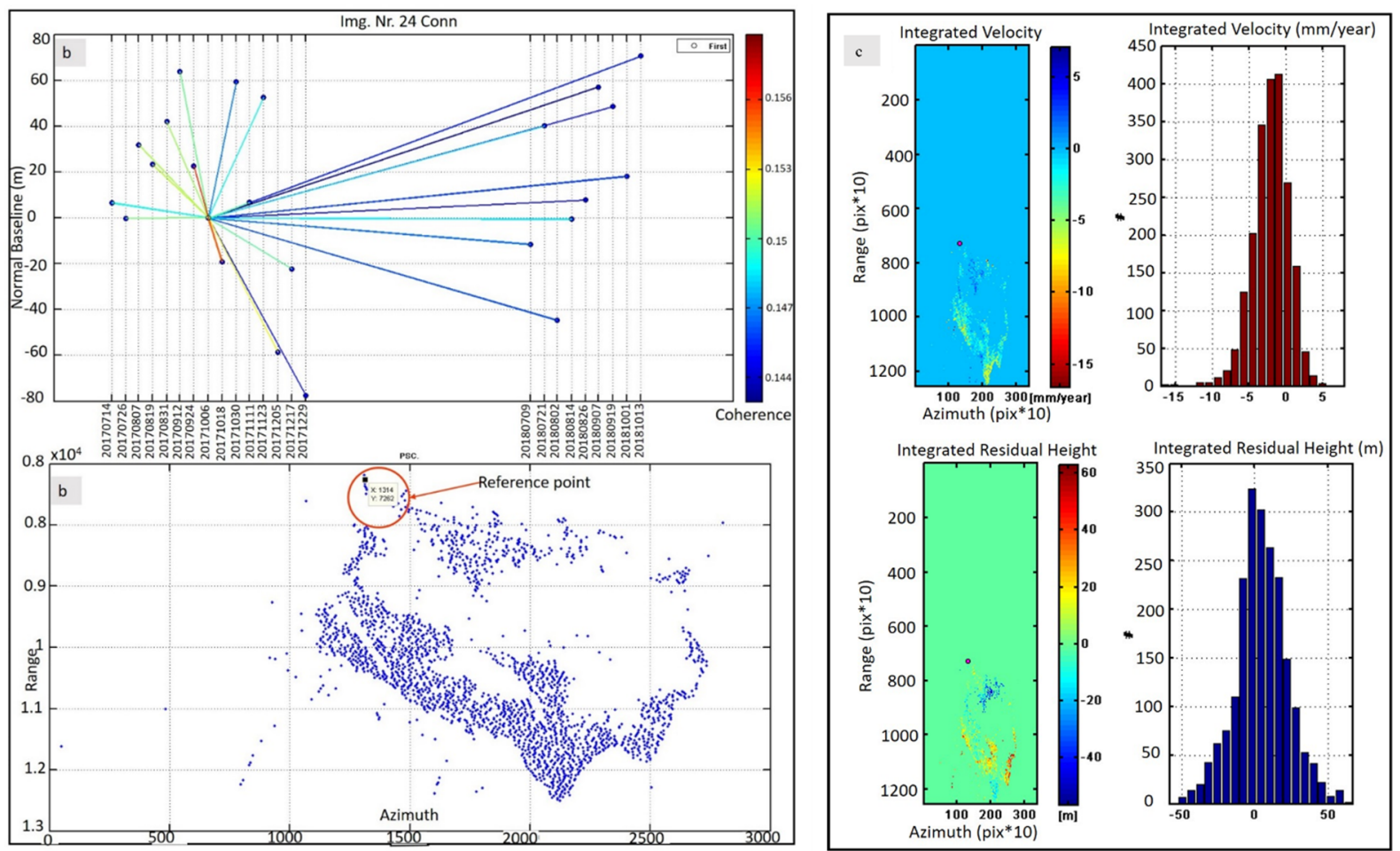

Fig. 4 Spatiotemporal baseline connection graphs of master and slave pair images (a), Ground Control Point (GCP) for the descending orbit (b), and integrated residual height (m) to zero reference point for orbit (c).

A classical star image graph is implemented in this work, where all images used are connected to a single selected master image, as shown in Figure 4a. The most stable reference point was achieved when $\mathrm{x}$ is 1314 and $y$ is 7262 (Fig. 4b) at the maximum residual height of point zero, as depicted in Figure 4c. Coregistration of the images was performed to match all the data without any spatial errors before interferograms were created.

Residual height is the residual height concerning the reference point after integrating the connections residual height using the given graph. Integrated velocity is the velocity concerning the reference point after integrating the velocity of the connection using the given graph. Interferograms were generated based on the loaded image graph in SARPROZ. The data (long spatial wavelengths produced by atmospheric distortions) were filtered by applying Goldstein modification filtering and the multi-look factor to remove the vegetation and noises. The atmospheric disturbances were removed using the Goldstein mode. The smoothest interferograms were found and selected after three (3) rounds of filtering with $15 * 15$, $20 * 20$, and $25 * 25 \mathrm{ML}$ factors. The linear trend model was adopted for the PS using temporal coherence of 0.8 , linear trend value of $5 \mathrm{~mm} / \mathrm{yr}$, and $20 \mathrm{~m}$ as the height value in the software. Finally, the results were geocoded to Google Earth by selecting orthorectify for the exportation of the results. Buildings, light posts, road signs, and other concrete structures that reflect the radar signal well are among the persistent scatterers candidates (PSCs) in AOI. The velocity data obtained from the InSAR technique were analysed via the statistical package for the social sciences (SPSS) version 25. Descriptive statistics were generated, and regression analysis was used. The descriptive analysis provides the user with the understanding of the exact data and values and the users' scale of concern

\section{GROUND-PENETRATING RADAR (GPR)}

GPR is one of the most widely used geophysical techniques for subsurface imaging (Kannaujiya et al., 2019). The configuration consists of a GSSI $300 / 800$ $\mathrm{MHz}$ dual-frequency antenna, an electronic unit, a $10.8 \mathrm{~V}$ lithium-ion battery, a large wheel, and a monitor. The wheel was calibrated and ensured to travel in a straight line for data accuracy. The antenna has both the transmitter and receiver components connected to the monitor and battery. The optical data cable was tightly connected to the antenna. The communication cable was connected between the antenna and monitor. The mode of operation depends on transmitting pulses of high-frequency electromagnetic energy into the ground from the surface. The transmitted waves (from different submerged objects and earth materials) are reflected to the surface as they encounter changes in the matrix's dielectric permittivity. The energy is detected by a receiver antenna (Fig. 5a). The results depend on the soil type and the equipment used. The monitor was used to visualise and interpret the acquired data (at Batu Ferringhi, BF, and Tanjung Bungah, TB). 


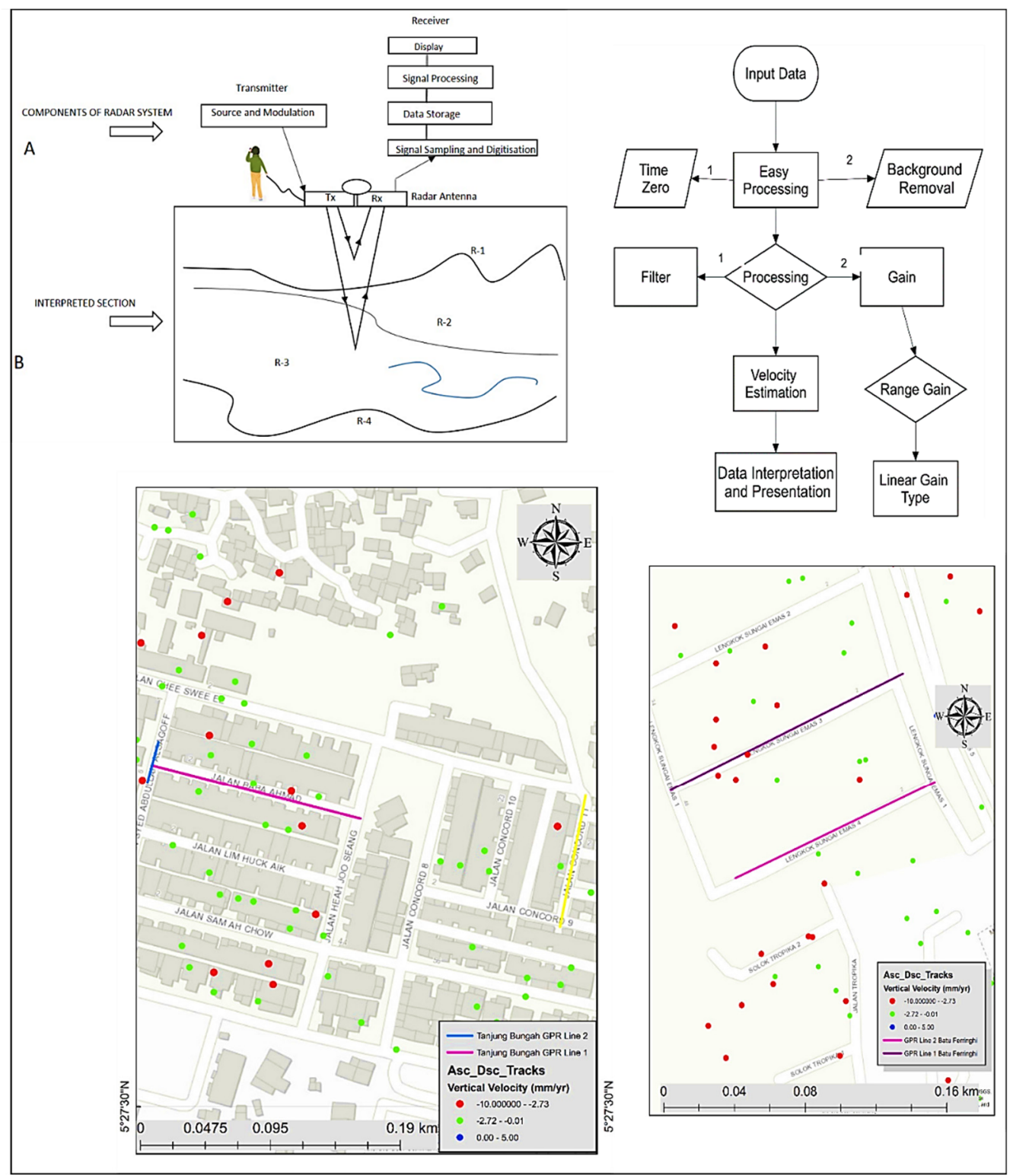

Fig. 5 (a) GPR methodology, (b) Flowchart of GPR processing, and GPR survey lines at (c) TB and (d) BF.

Figure $5 \mathrm{~b}$ shows the flowchart of the processing steps for the GRP data. RADAN 7 software of Geophysical Survey Systems, Inc. was used to perform the profile processing. The basics steps used to process, filter the high noise, and enhance the target are- time-zero, background removal, gain, and velocity estimation (Schrott and Sass, 2008). The survey lines of the studied areas are shown in Figures $5 \mathrm{c}$ and $5 \mathrm{~d}$ for the Tanjung Bungah and Batu Ferringhi areas, respectively.

\section{RESULTS AND DISCUSSIONS}

In this analysis, S-1A IW images were processed with SARPROZ software to detect PS points. Due to the high density of ground targets in urban areas, the PS-InSAR technique was applied to select pixels for monitoring the area's displacement. The detailed summary of the average line of sight (LOS) velocities determined from S-1A data is presented in the RGB colour scale in Figure 6. The result of the descending orbit dataset over the entire Penang Island is shown in Figure 6. The PS points are well spread across the region's urban areas due to high reflectivity (e.g., high-rise buildings, artificial structures such as buildings, lamp posts, road signs, highways, airports, and other concrete structures). Subsidence patterns (red and green colours) are observed in the selected areas (red boxes). Different colours of the image correspond to different displacement values of PS. The red colours indicate high subsidence and correspond to unstable targets (i.e., the target moves away in the LOS direction from the sensor, implying that the areas are subsiding). The blue colours signify that the areas are uplifting (where the target's movement is towards 


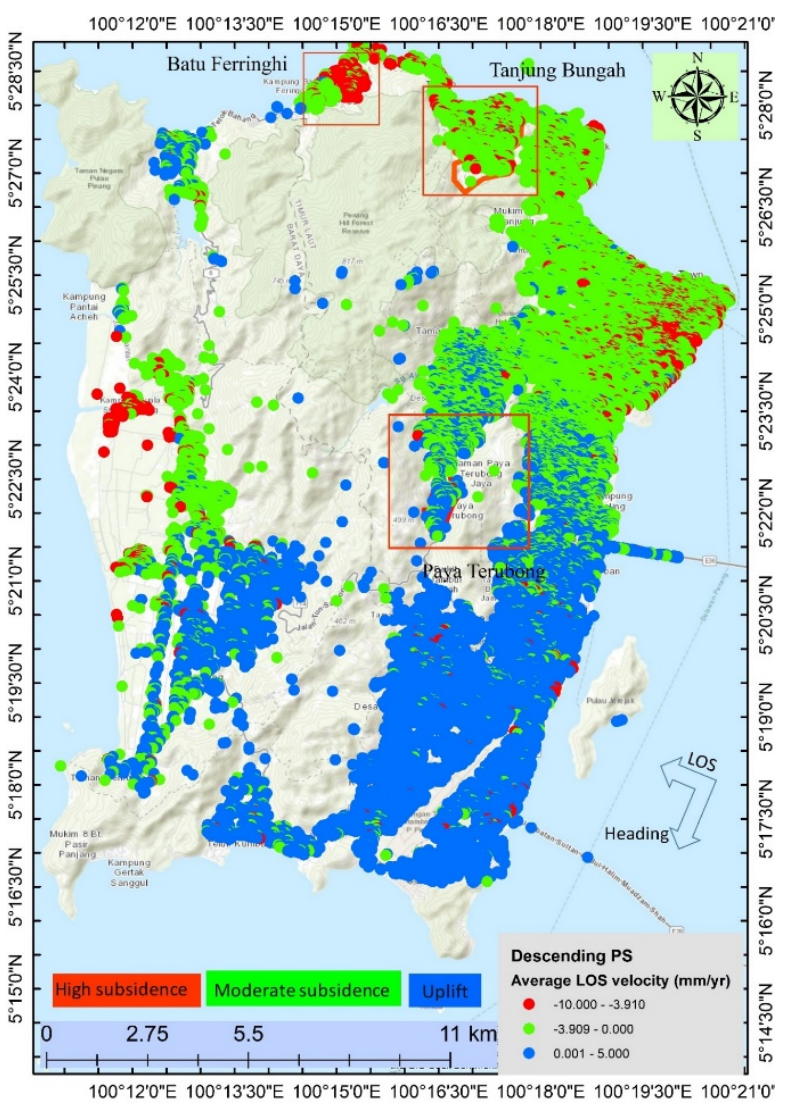

the sensor in the LOS direction). More PS points are observed for urban areas (due to many structures) and fewer for rural areas (where there are vegetation and sparse urbanisation) of the same scale. On average, the islands' landslides occur at peak rainfall, usually between October and January (Pradhan and Lee, 2010).

\section{VALIDATION OF INSAR RESULT}

As many factors do affect the InSAR technique's accuracy, it is essential to validate the method. One of the in situ measurements used to comply with high precision criteria is the Global Positioning System (GPS). The analysis of Ami et al. (2015) is used to validate the InSAR results in this research. The acquired GPS data between 1999 and 2011 from 117 stations were used to assess Malaysia's vertical displacement pattern. The results show the vertical ground movements (uplift and subsidence) of Malaysia. The values of the deformation range from -0.04 to $-34.41 \mathrm{~mm} / \mathrm{yr}$ (subsidence) and from $0.21 \mathrm{~mm} / \mathrm{yr}$ to $1.44 \mathrm{~mm} / \mathrm{yr}$ (uplift). In Penang Island (USMP station), $-0.90 \mathrm{~mm} / \mathrm{yr}$ of ground deformation value was detected (Fig. 7a), indicating subsidence in the area. This value coincides with the observed value using PS-InSAR techniques simultaneously in this work (Fig. 7b).

Fig. 6 Average velocity map of land deformation (2017-2018), Penang Island. Red, green, and blue points indicate high subsidence, moderate subsidence, and uplift areas. Ground subsidence is evident in the area of interest (red boxes).

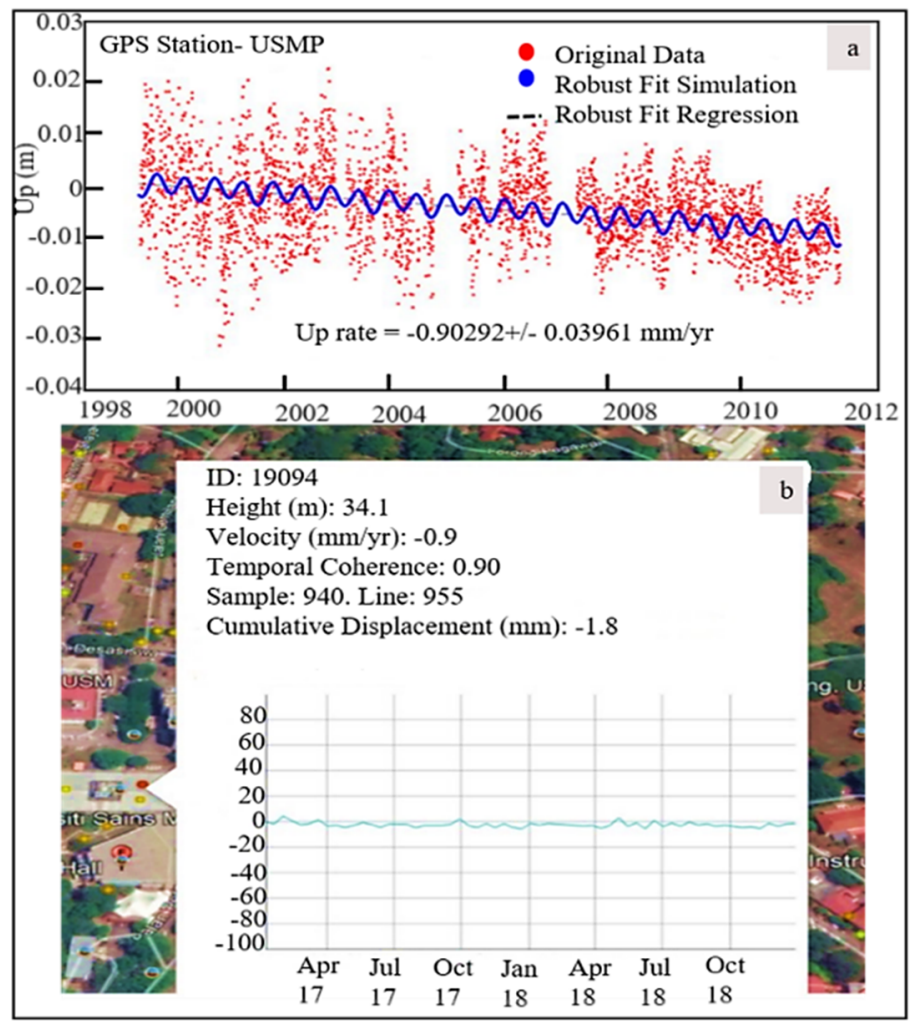

Fig. 7 Vertical displacement of GPS measurement at USMP station (a), PS points obtained by S-1A data (b). 


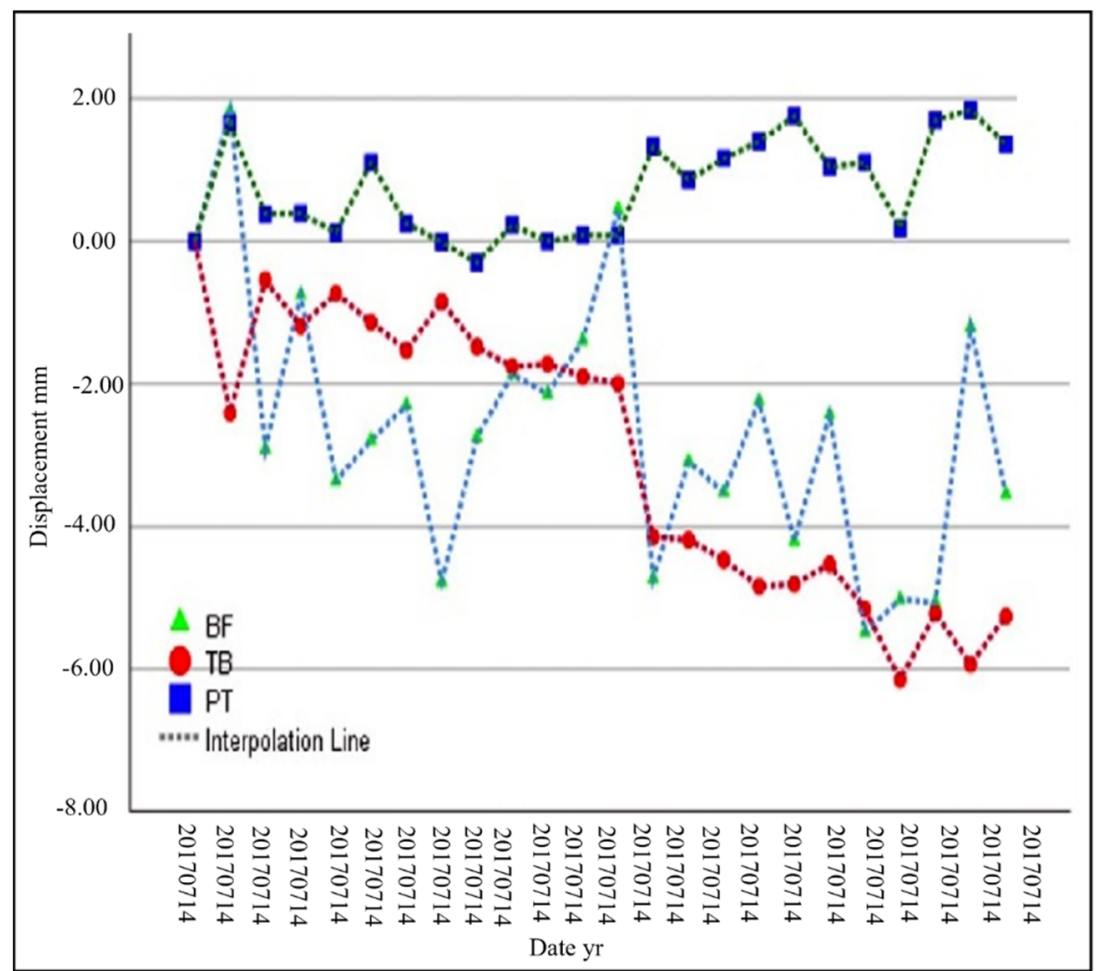

Fig. 8 (a) Tanjung Bungah, (b) Paya Terubong, and (c) Batu Ferringghi displacement time series. (1d) Overall time series of the PS points for the descending track.

\section{STATISTICAL ANALYSIS OF INSAR RESULTS}

In the frequency distribution of landslides of the three core locations considered in the study, the total PS points of 1555 were calculated. 77 out of the total points were located in Batu Ferringhi, 1248 points in Tanjung Bungah, and 230 points in Paya Terubong with $5.00 \%, 80.22 \%$, and $18.80 \%$, respectively. The displacement rates in Batu Ferringhi, Tanjung Bungah, and Paya Terubong areas are respectively $-3.13 \mathrm{~mm} / \mathrm{yr}$ and $-2.76 \mathrm{~mm} / \mathrm{yr}$ and $-4.77 \mathrm{~mm} / \mathrm{yr}$. Figure 8 shows time-series graphs of the rate of displacements that correspond with the landslide occurrences in the areas. Tanjung Bungah and Batu Ferringhi show some deformations (from $5^{\text {th }}$ to $17^{\text {th }}$ December 2017) that correlate with the landslide events that happened on the island. The landslide occurrences were triggered by heavy rain that lasted for over ten hours. Most landslides on the island occur between October and January, when rainfall peaks (Yahaya et al., 2019).

Generally, the soil of Penang Island contains weak clay, silt, and gravel. Environmental circumstances such as rain can slide down the soil due to gravity. The sparse vegetation (like grass and shrubs) covers the soil's clayey material, which can slip in a significant percentage during rainfall. Erosion of concentrated rainwater penetrates clayey surfaces and triggers old landslide cracks. Paya Terubong's main deposit is clay, making it the most vulnerable ground deformation area in Penang Island. Batu Ferringhi has less ground deformation than Paya
Terubong because of the higher volume of gravel. According to Ahmad et al. (2014), the soil at Tanjung Bungah has high water content and is vulnerable to shallow landslides. The PS-InSAR analysis shows that the studied areas have linear tendencies to deformations.

Figure 9 shows the maps of the three prone areas for comparison. The PS points for each area were extracted and overlaid on the topographic map of the island. Ground movements (uplift and subsidence) were observed during the monitoring. In Tanjung Bungah (Fig. 9a), both the low elevation (flat) and deformation (i.e., subsiding) areas are well correlated. Paya Terubong (Fig. 9b) exhibits a similar observation (with Tanjung Bungah) in the northern part. Although, in the southern part of the area, uplift patterns are found on the high topography. Figure 9c shows how the two forms of deformations (subsidence and uplift) are distributed across Batu Feringghi's topographic regions.

\section{RESULTS AND INTERPRETATION OF GPR PROFILES}

GPR surveys were conducted across some subsidence areas detected using the InSAR method to characterise and interpret subsoil features. The detected subsurface anomalies and shallow depression on the plotted GPR profile (Fig. 10) are probably associated with fractures and road fissures. Figures 10a-c show the radargrams with various anomalies at three survey sites of Tanjung Bungah, 


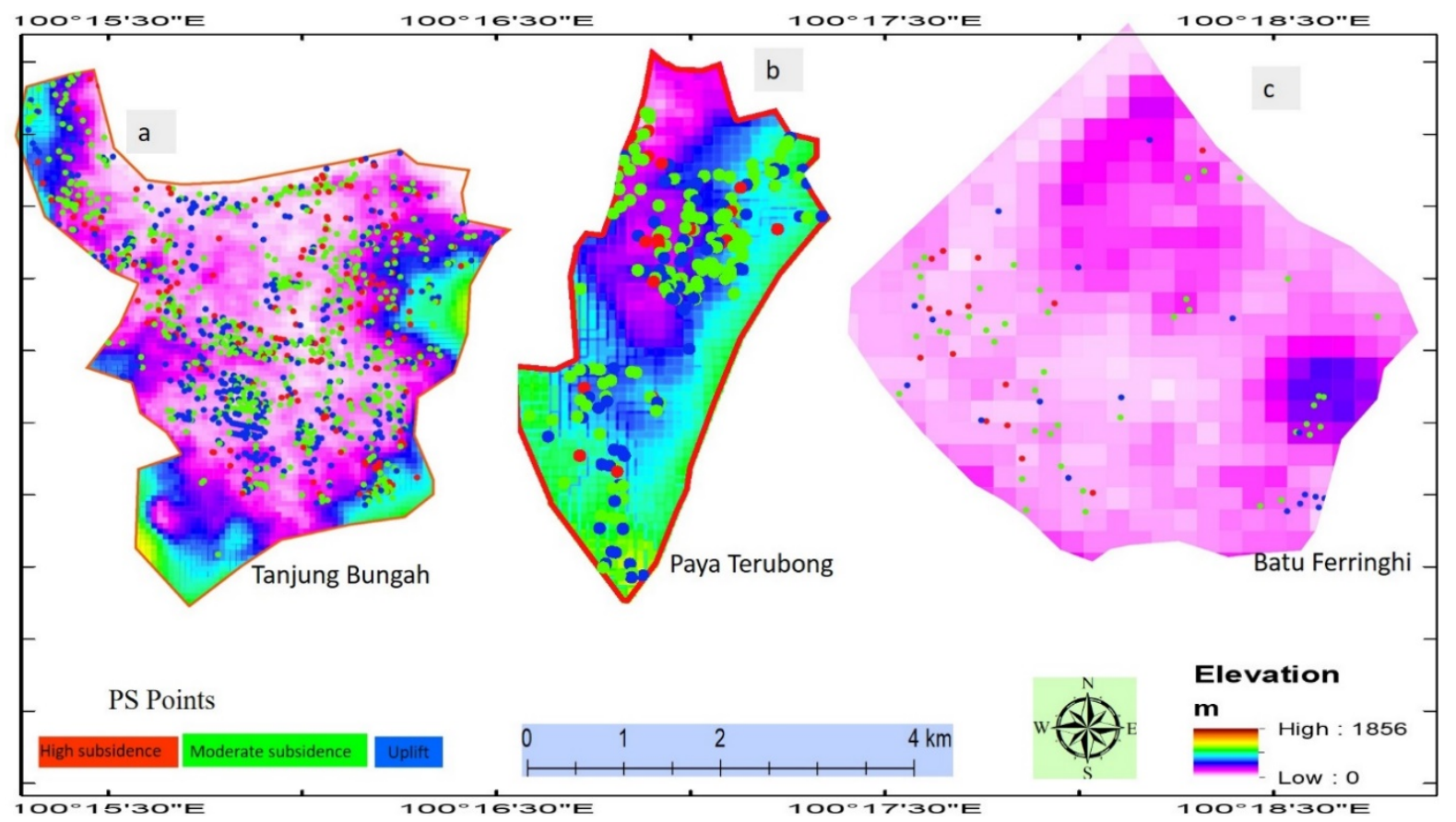

Fig. 9 Map of the three studied areas with their PS distribution overlaid on DEM. (a) Tanjung Bungah, (b) Paya Terubong, and (c) Batu Ferringhi.

and Figures 10d-e show the two survey sites of Batu Ferringhi. An anomaly was observed at a distance of $11.64 \mathrm{~m}$ and a depth of $1.20 \mathrm{~m}$ at the first survey site in Tanjung Bungah, as shown in Figure 10a. This observed anomaly corresponds to the deformation value $(-3.93 \mathrm{~mm} / \mathrm{yr})$ obtained from InSAR. Figure $10 \mathrm{~b}$ depicts the radar graph at the second survey site of Tanjung Bungah, where different anomalies were detected. The detected anomaly located at a distance of $27.86 \mathrm{~m}$ with a depth of $0.34 \mathrm{~m}$ from the starting point corresponds to deformation values of $-5.57 \mathrm{~mm} / \mathrm{yr}$. Figure 10c illustrates the observed two road fractures with deformation values of $-2.24 \mathrm{~mm} / \mathrm{yr}$ and $7.33 \mathrm{~mm} / \mathrm{yr}$ at respective distances of $10.70 \mathrm{~m}$ and $21.22 \mathrm{~m}$ with respective depths of $1.10 \mathrm{~m}$ and $0.78 \mathrm{~m}$. The Batu Ferringhi profile's radar graph is presented in Figures 10d-e, where different anomalies are observed. The detected deformations values of $-4.00 \mathrm{~mm} / \mathrm{yr},-5.44 \mathrm{~mm} / \mathrm{yr}$, and $-5.19 \mathrm{~mm} / \mathrm{yr}$ were at distances $0.88,6.34$, and $16.36 \mathrm{~m}$ from the starting points at the depths of $0.95,0.62$, and $0.27 \mathrm{~m}$, respectively (Fig. 10d). Lastly, the GPR survey's radar graph carried out at the second survey site of Batu Ferringhi is depicted in Figure 10e. Various anomalies (road fissures, drains) were seen at the site. The deformation values of $-3.51 \mathrm{~mm} / \mathrm{yr}$ correspond to the anomaly located at a distance of $1.6 \mathrm{~m}$ with $0.6 \mathrm{~m}$ depth.

\section{CONCLUSIONS}

Penang Island is a tourist attraction region with roughly $300 \mathrm{~km}^{2}$ of the land but has limited flat terrain.
A significant part of the land on the island is the hill. This paper presents the application of the PS-InSAR technique to process the C-band S-1A data for monitoring ground deformation in three different areas of Penang Island, i.e., Tanjung Bungah, Paya Terubong, and Batu Ferringhi, where huge landslide events had happened. PS-InSAR technique is a versatile method for detecting instabilities on the slope and quantifying their rate of displacements. It shows the potential to obtain results more efficiently than conducting in-situ measurements using on-site instrumentation. The results show that the deformations along the region are detected by PS-InSAR analysis. Significant mean deformations values of -3.13 and $-2.76 \mathrm{~mm} / \mathrm{yr}$ and $-4.77 \mathrm{~mm} / \mathrm{yr}$ in the direction of LOS at the respective areas of Batu Ferringhi, Tanjung Bungah, and Paya Terubong were detected. In addition to the suspected factors, the deformations at Tanjung Bungah and Paya Terubong might be connected to the main fault that travels through the north-south regions and segregates the island into two, as depicted in Figure 1b. This has also been reported by Yahaya et al. (2019). The displacement at Paya Terubong can also be related to underground water movement in the zone, as discovered using geophysical measurement (Rauff et al., 2020a). However, the result is not presented in this work since it is not within the scope. One approach cannot be used as a stand-alone tool for solving landslide challenges in an urban area. This work has demonstrated the reliability and efficiency of S-1A data in urban areas for the PS-InSAR analysis. 


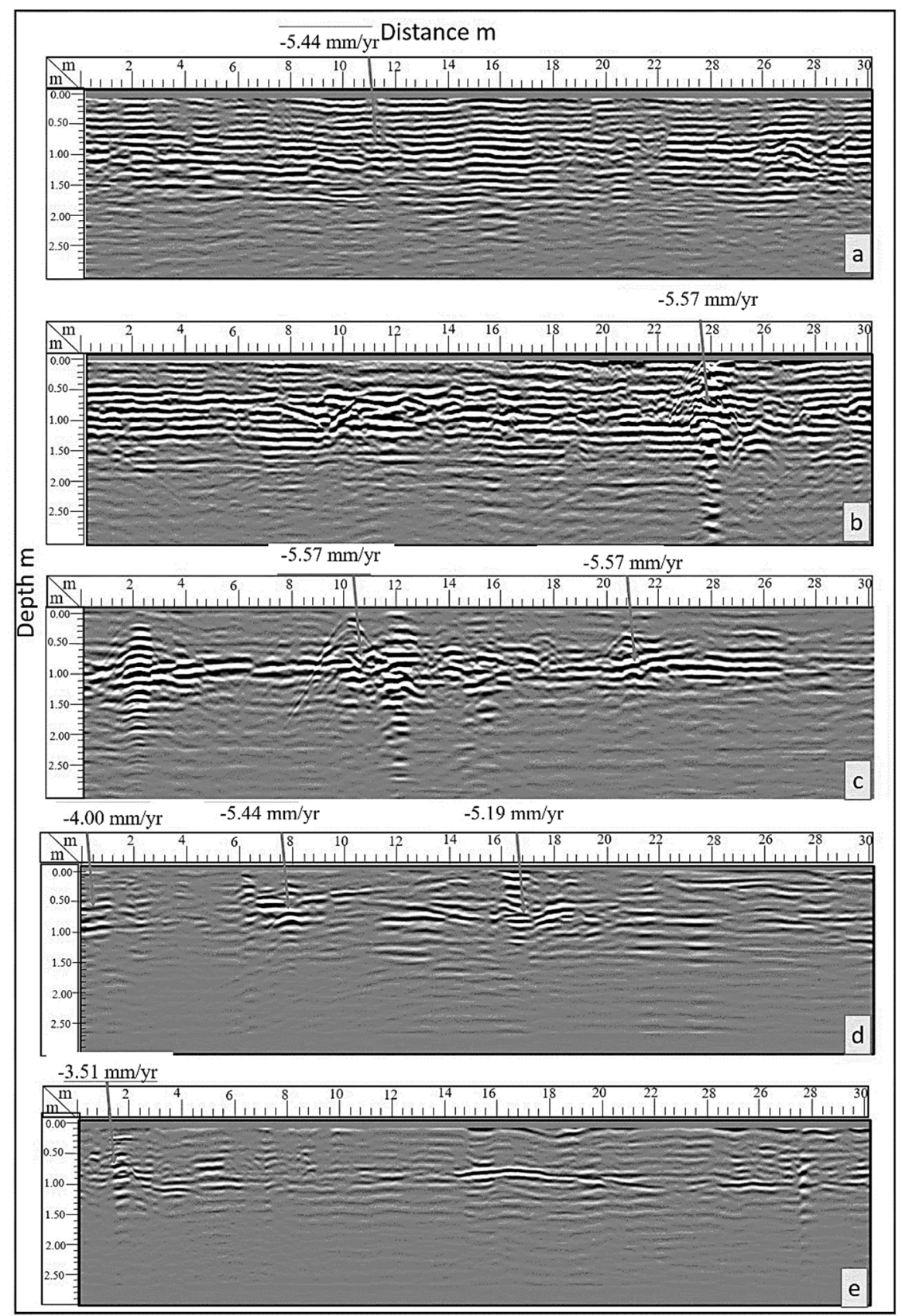

Fig. 10 The radargrams at three areas of Tanjung Bungah (a-c) and two Batu Ferringhi areas (d and e).

\section{REFERENCES}

Adnan, A. Hendriyawan, H., Marto, A. and Irsyam, M.: 2005, Seismic hazard assessment for Peninsular Malaysia using Gumbel distribution method. J. Teknol. B, 42, 42B, 57-73. DOI: 10.11113/jt.v42.741

Ahmad, F., Yahaya, A.S. and Farooqi, M.A.: 2006, Characterisation and geotechnical properties of Penang residual soils with emphasis on landslides. Am. J. Sci., 2, 121-128.

DOI: 10.3844/AJESSP.2006.121.128

Ahmad, F., Yahaya, A.S., Halim, M.H. and Sian, K.C.: 2014, Analysis of thickness of sand and silt in Penang Island. J. Civ. Eng. Res., 4, 3, 41-47.
Ali, M.M., Ahmad, F., Yahaya, A.S. and Farooqi, M.A.: 2011, Characterisation and hazard study of two areas of Penang Island, Malaysia. Hum. Ecol. Risk Assess., 17, 4, 915-922. DOI: 10.1080/10807039.2011.588156

Ami, H.M.D., Mohd Nadzri, M.R., Kamaludin, M.O. and Sahrum Ses, A.S.A.: 2015, Monitoring vertical land motion in Malaysia using global positioning system (GPS). 36 ${ }^{\text {th }}$ Asian Conference on Remote Sensing, Conference Paper, 11 pp.

Bakon, M., Papco, J., Perissin, D., Sousa, J.J. and Lazecky, M.: 2016, Multi-sensor InSAR deformation monitoring over urban area of Bratislava (Slovakia). Procedia Comput. Sci., 100, 1127-1134. DOI: $10.1016 /$ j.procs.2016.09.265Get 
Bayer, B., Simoni, A., Schmidt, D. and Bertello, L.: 2017, Using advanced InSAR techniques to monitor landslide deformations induced by tunnelling in the Northern Apennines, Italy. Eng. Geol., 226, 20-32. DOI: 10.1016/j.enggeo.2017.03.026

Chee, S.Y., Othman, A.G., Sim, Y.K., Mat Adam, A.N. and Firth, L.B.: 2017, Land reclamation and artificial islands: Walking the tightrope between development and conservation. Glob. Ecol. Conserv., 12, 80-95. DOI: 10.1016/j.gecco.2017.08.005

Cobbing, E.J., Mallick, D.I.J., Pitfield, P.E.J. and Teoh, L.H.: 1986, The granites of the southeast Asian tin belt. J. Geol. Soc., 143, 3, 537-550.

Crosetto, M., Monserrat, O., Devanthéry, N., CuevasGonzález, M., Barra, A. and Crippa, B.: 2016, Persistent scatterer interferometry using Sentinel-1 data. ISPRS Archives, 41, 835-839.

DOI: 10.1016/j.procs.2016.09.118

Lee, S. and Pradhan, B.: 2006, Probabilistic landslide hazards and risk mapping on Penang Island, Malaysia. J. Earth Syst. Sci., 115, 661-72.

Lu, Z.: 2007, InSAR imaging of volcanic deformation over cloud- prone Areas-Aleutian Islands. Photogramm. Eng. Remote Sens., 245-257. DOI: 10.14358/PERS.73.3.245

Mirzaee, S., Motagh, M. and Akbari, B.: 2017, Landslide monitoring using InSAR time-series and GPS observations, case study: Shabkola landslide in northern Iran. Remote Sens. Spat. Inf. Sci., 42, 487492.

DOI: 10.5194/isprs-archives-XLII-1-W1-487-2017

Navarro-Sanchez, V.D., Lopez-Sanchez, J.M. and FerroFamil, L.: 2014, Polarimetric approaches for persistent scatterers interferometry. IEEE Trans. Geosci. Remote Sens., 52, 3, 1667-1676.

DOI: $10.1109 /$ TGRS.2013.2253111

Paradella, W.R., Ferretti, A., Mura, J.C., Colombo, D., Gama, F.F., Tamburini, A., Santos, A.R., Novali, F., Galo, M., Camargo, P.O., Silva, A.Q., Silva, G.G., Silva, A. and Gomes, L.L.: 2015, Mapping surface deformation in open pit iron mines of Carajás Province (Amazon Region) using an integrated SAR analysis. Eng. Geol., 193, 61-78. DOI: $10.1016 /$ j.enggeo.2015.04.015

Perissin, D.: 2015, SARPROZ: The SAR PROcessing tool by periZ. Available online: http://www.sarproz.com/

Pradhan, B. and Lee, S.: 2010, Delineation of landslide hazard areas on Penang Island, Malaysia, by using frequency ratio, logistic regression, and artificial neural network models. Environ. Earth Sci., 60, 5, 1037-1054.

Pradhan, B. and Lee, S.: 2010, Delineation of landslide hazard areas on Penang Island, Malaysia, by using frequency ratio, logistic regression, and artificial neural network models. Environ. Earth Sci., 60, 5, 1037-1054. DOI: 10.1007/s12665-009-0245-8

Pradhan, B., Chaudhari, A., Adinarayana, J. and Buchroithner, M.F.: 2012, Soil erosion assessment and its correlation with landslide events using remote sensing data and GIS: A case study at Penang Island, Malaysia. Environ. Monit. Assess., 184, 715-727. DOI: 10.1007/s10661-011-1996-8

Pradhan, B. and Hasan, M.: 2014, Land subsidence susceptibility mapping at Kinta Valley (Malaysia) using the evidential belief function model in GIS. Nat. Hazards, 73, 1019-1042.

DOI:10.1007/s11069-014-1128-1
Rauff, K.O., Ismail A.A. and Perissin, D.: 2020a, Characterisation of landslide using InSAR technique and electrical resistivity method at Paya Terubong, Malaysia. J. Indian Soc. Remote Sens., 48, 8, 1223 1236. DOI: $10.1007 / \mathrm{s} 12524-020-01150-3$

Rauff, K.O., Ismail A.A. and Qadir, A.: 2020b, Effect of land reclamation on water using remote sensing techniques, Penang Island. Indian J. Ecol., 47, 2, 290 294.

Razi, P., Sumantyo, J.T.S., Perissin, D., Kuze, H., Chua, M.Y. and Panggabean, G.F.: 2018, 3D land mapping and land deformation monitoring using persistent scatterer interferometry (PSI) ALOS PALSAR: Validated by Geodetic GPS and UAV. IEEE Access, $6,12395-12404$ DOI: 10.1109/ACCESS.2018.2804899

Ruiz-Constán, A., Ruiz-Armenteros, A.M., Martos-Rosillo, S., Galindo-Zaldivar, J., Lazecky, M., Garcia, M., Sousa, J.J., Sanz de Galdeao, C., Delgado-Blasco, J.M., Caro-Cuenca, P. and Luque-Espinar, J.A.: 2018, SAR interferometry monitoring of subsidence in a detritic basin related to water depletion in the underlying confined carbonate aquifer (Torremolinos, southern Spain). Sci. Total Environ., 636, 670-687. DOI: $10.1016 /$ j.scitotenv.2018.04.280

Schrott, L. and Sass, O.: 2008, Application of field geophysics in geomorphology: Advances and limitations exemplified by case studies. Geomorphology, 93, 1-2, 55-73. DOI: 10.1016/j.geomorph.2006.12.024

Sousa, J.J., Ruiz, A.M., Bakoň, M., Lazecky, M., Hlaváčová, I., Patrício, G., Delgado, J.M. and Perissin, D.: 2016, Potential of C-Band SAR Interferometry for Dam Monitoring. Procedia Comput. Sci., 100, 1103-1114.

Tan, B.K.: 1994, Engineering properties of granitic soils and rocks of Penang Island, Malaysia. Bull. Geol. Soc. Malaysia, 35, 69-77.

Tan, K.C., Lim, H.S., MatJafri, M.Z. and Abdullah, K.: 2009, Landsat data to evaluate urban expansion and determine land use/land cover changes in Penang Island, Malaysia. Environ. Earth Sci., 60, 7, 15091521. DOI: $10.1007 / \mathrm{s} 12665-009-0286-\mathrm{z}$

The Star Malaysia, 2019, Penang landslide chronology 2017-June 2019: 2019, The Star Graphics. https://www.pressreader.com/.

Yahaya, N.S., Ramli, Z., Thompson, A. and Pereira, J.J.: 2019, Landslides in Penang Island, Malaysia: Insights on emerging issues and the role of geoscience. Warta Geologi, 45, 4, 37-43.

Yague-Martinez, N., Prats-Iraola, P., Gonzalex, F.R., Brcic, R. Shau, R., Geudtner, D., Eineder, M. and Bamler, R. 2016, Interferometric Processing of Sentinel-1 TOPS Data. IEEE Trans. Geosci. Remote Sens., 54, 4, 2220 2234. DOI: 10.1109/TGRS.2015.2497902 